\title{
Adsorpsi Logam Tembaga (Cu), Mangan (Mn) dan Nikel (Ni) dalam Artificial Limbah Cair dengan Menggunakan Nanopartikel Magnetit $\left(\mathrm{Fe}_{3} \mathrm{O}_{4}\right)$
}

\author{
Diah Mahmuda, Nurhidayati Sakinah, dan Edi Suharyadi \\ Jurusan Fisika, Fakultas MIPA, Universitas Gadjah Mada, Yogyakarta, Indonesia \\ Sekip Utara PO BOX BLS.21 Yogyakarta 55281, Indonesia \\ *Corresponding Author : esuharyadi@ugm.ac.id
}

Received 30-05-2014, Revised 24-06-2014, Accepted 15-07-2014, Published 31-10-2014

\begin{abstract}
Magnetite $\left(\mathrm{Fe}_{3} \mathrm{O}_{4}\right)$ nanoparticles have been successfully synthesized using co-precipitation method and have been used for removing $\mathrm{Cu}, \mathrm{Mn}$ and $\mathrm{Ni}$ metals ions from artificial wastewater. Ability of removing metal ions with $\mathrm{Fe}_{3} \mathrm{O}_{4}$ against $\mathrm{pH}$, adsorbent particle size, readsorption and by addition of Polyethylene Glycol (PEG-4000) as coating agent of adsorbent have been studied. The adsorption process was found to be $\mathrm{pH}$-dependent. Maximum adsorption at $\mathrm{pH} 12$ for most of the metal ions with percent of sorption $\mathrm{Cu} 99.79 \%$, $\mathrm{Ni} 69.83 \%$ and $\mathrm{Mn} 44.53 \%$. Using adsorbent with $12 \mathrm{~nm}$ of particles size, readsorption process and by addition of Polyethylene Glycol (PEG-4000) as coating agent of adsorbent also made the ability of removing metals ions increasing. Preliminary results indicate that magnetite nanoparticles may be used as an adsorbent for removal of $\mathrm{Cu}, \mathrm{Mn}$ and $\mathrm{Ni}$ from wastewater.
\end{abstract}

Keywords: nanoparticle, adsorption, metal ion, adsorbent, $\mathrm{Fe}_{3} \mathrm{O}_{4}$

\section{ABSTRAK}

Nanopartikel magnetit $\left(\mathrm{Fe}_{3} \mathrm{O}_{4}\right)$ telah berhasil disintesis menggunakan metode kopresipitasi dan digunakan sebagai adsorben untuk menurunkan kadar ion logam $\mathrm{Cu}, \mathrm{Mn}$ dan $\mathrm{Ni}$ dalam artificial limbah. Pengaruh $\mathrm{pH}$ larutan, ukuran partikel adsorben, readsorpsi (pengulangan), dan pelapisan adsorben dengan Polyethylene glycol (PEG-4000) dengan perbandingan massa 1:1 terhadap penurunan kadar logam telah dilakukan dalam penelitian ini. Prosentase penurunan kadar logam $\mathrm{Cu}^{+2}, \mathrm{Mn}^{+2}$ dan $\mathrm{Ni}^{+2}$ diketahui meningkat seiring dengan peningkatan $\mathrm{pH}$. Penurunan kadar logam maksimum terjadi pada $\mathrm{pH} 12$ (kondisi basa) masing-masing untuk $\mathrm{Cu}$ 99,79\%, Ni 69,83\% dan Mn 44,53\%. Selain itu, penggunaan adsorben $\mathrm{Fe}_{3} \mathrm{O}_{4}$ dengan ukuran 12 $\mathrm{nm}$ juga lebih efektif menyerap logam lebih banyak daripada $\mathrm{Fe}_{3} \mathrm{O}_{4}$ dengan ukuran $80 \mu \mathrm{m}$. Peningkatan penyerapan logam juga tampak saat dilakukan proses pengulangan (readsorpsi) dan saat menggunakan adsorben yang dilapisi dengan PEG. Hasil penelitian ini mengindikasikan bahwa nanopartikel $\mathrm{Fe}_{3} \mathrm{O}_{4}$ dapat digunakan sebagai salah satu adsorben untuk menurunkan kadar $\operatorname{logam} \mathrm{Cu}, \mathrm{Mn}$ dan $\mathrm{Ni}$ dalam limbah cair.

Kata kunci: nanopartikel, adsorpsi, ion logam, adsorben, $\mathrm{Fe}_{3} \mathrm{O}_{4}$ 


\section{PENDAHULUAN}

Penelitian nano-teknologi di bidang lingkungan khususnya penanggulangan pencemaran logam berat menaruh perhatian besar pada adsorben berbasis nanopartikel karena lebih murah dari sisi biaya, lebih efisien waktu, mudah diproduksi serta terbukti mampu menanggulangi pencemaran air oleh logam berat. Salah satu nanopartikel yang menjadi fokus dalam menangani masalah pencemaran air oleh logam berat adalah nanopartikel magnetik $\mathrm{Fe}_{3} \mathrm{O}_{4}$ (magnetit) ${ }^{[1]}$.

Magnetit dipilih karena memiliki sifat magnetik yang kuat. Sifat magnetiknya sebagian besar dipengaruhi oleh morfologi, ukuran dan karakteristik fisika dari partikel tunggal, dan interaksi antarmuka. Untuk partikel dengan ukuran kurang dari $30 \mathrm{~nm}$, magnetit menunjukkan sifat-sifat super paramagnetik. Selain itu luas permukaan partikel yang besar juga menjadi salah satu keunggulan nanopartikel magnetik sehingga memiliki kapasitas besar untuk mengadsorpsi ion logam berat ${ }^{[2]}$. Karena sifatnya yang mudah teroksidasi, magnetit seringkali dimodifikasi dengan dilapisi menggunakan polimer atau silika ${ }^{[3]}$.

Logam seperti $\mathrm{Cu}, \mathrm{Mn}$ dan $\mathrm{Ni}$ sangat sedikit diteliti dan sangat sulit ditemukan diberbagai literatur. Pada penelitian ini dilakukan proses adsorpsi logam $\mathrm{Cu}$, Mn dan Ni menggunakan adsorben nanopartikel magnetit. Tujuannya adalah untuk melihat efektifitas penggunaan nanopartikel magnetit dalam mengadsorpsi ion $\operatorname{logam~} \mathrm{Cu}, \mathrm{Mn}$, dan $\mathrm{Ni}$, dibawah pengaruh variasi ukuran partikel magnetit $(80 \mu \mathrm{m}$ dan $12 \mathrm{~nm}), \mathrm{pH}(5 ; 9 ; 12)$, pengaruh readsorpsi, dan pelapisan magnetit dengan Polyethylene glycol (PEG-4000) dengan perbandingan massa 1:1.

\section{METODE}

\section{Adsorben $\mathrm{Fe}_{3} \mathrm{O}_{4}$}

Proses sintesis nanopartikel $\mathrm{Fe}_{3} \mathrm{O}_{4}$ dilakukan dengan melarutkan $\mathrm{FeSO}_{4} \cdot 7 \mathrm{H}_{2} \mathrm{O}$ dan $\mathrm{FeCl}_{3} .6 \mathrm{H}_{2} \mathrm{O}$ ke dalam $\mathrm{H}_{2} \mathrm{O}$ (aquades). Selanjutnya, ke dalam larutan tersebut ditambahkan larutan $\mathrm{NH}_{4} \mathrm{OH} 10 \%$ secara perlahan dan diaduk diatas magnetik stirrer pada suhu $60{ }^{\circ} \mathrm{C}$ dengan kecepatan aduknya $450 \mathrm{rpm}$. Larutan $\mathrm{Fe}_{3} \mathrm{O}_{4}$ kemudian dicuci dengan aquades sampai bau dari $\mathrm{NH}_{4} \mathrm{OH}$ hilang. Selanjutnya dilakukan proses dekantasi (pengendapan) dengan bantuan medan magnet eksternal agar proses pengendapan dapat dilakukan dengan lebih cepat. Endapan selanjutnya dikeringkan di dalam furnace pada suhu $80{ }^{\circ} \mathrm{C}$ selama 2 jam. Sampel yang kering kemudian dianalisis ukuran butir, struktur kristal, dan sifat kemagnetannya menggunakan Transmission electron microscopy (TEM), X-RayDiffraction (XRD) dan Vibrating Sample Magnetometer (VSM).

\section{Serapan Logam Cu, Mn dan Ni}

Proses serapan logam dalam artificial limbah dilakukan dengan melarutkan 0,4 gram $\mathrm{Fe}_{3} \mathrm{O}_{4}$ kedalam $80 \mathrm{ml}$ limbah cair kemudian diaduk menggunakan magnetic stirrer. Diawal proses pengadukan, larutan diberi $\mathrm{NH}_{4} \mathrm{OH}$ dengan kadar yang disesuaikan dengan kondisi $\mathrm{pH}$ untuk masing-masing sampelnya. Larutan yang terbentuk selanjutnya diaduk menggunakan magnetic stirrer dengan waktu pengadukan 3 jam dan kondisi suhu ruang. Setelah proses pengadukan selesai, larutan diletakkan di atas magnet permanen selama satu jam. Selanjutnya, larutan yang telah dipisahkan dari endapan disaring dengan kertas saring, kemudian di AAS. Untuk sampel dengan variasi ukuran butir partikel $(80 \mu \mathrm{m}$ dan $60 \mathrm{~nm})$, readsorpsi, dan pelapisan magnetit dengan PEG-4000 dengan perbandingan massa 1:1, 
indikator lain dibuat tetap yaitu pada kondisi $\mathrm{pH}$ 9, suhu ruang, dan lama pengadukan 3 jam. Selanjutnya, prosentase penurunan kadar logam dihitung dengan rumus berikut.

$$
\% \text { penurunan }=\frac{\text { kadarawal-kadar akhir }}{\text { kadar awal }} \times 100 \%
$$

\section{HASIL DAN PEMBAHASAN}

Hasil XRD pada gambar 1. menunjukkan indikasi terbentuknya fasa $\mathrm{Fe}_{3} \mathrm{O}_{4}$ didalam sampel. Indikasi tersebut didasarkan pada nilai parameter kekisi yang diestimasi dari sudut $2 \theta=35,68^{\circ}$ yaitu pada puncak utama dengan indeks 311 . Dari hasil estimasi diperoleh nilai parameter kekisi 8,34 А dan jarak antar antar bidang kristalnya 0,251 nm, nilai parameter kekisi ini mendekati nilai parameter referensi kekisi $\mathrm{Fe}_{3} \mathrm{O}_{4}$ pada keadaan bulk $\left(8,397 \AA{ }^{[4]}\right.$. Indikasi terbentuknya fasa $\mathrm{Fe}_{3} \mathrm{O}_{4}$ pada sampel ini juga diperkuat dengan munculnya beberapa puncak difraksi lain dengan indeks miller (220), (400), (511) dan (440). Puncak difraksi dengan indeks miller tersebut merupakan indeks khas dari struktur spinel $\mathrm{Fe}_{3} \mathrm{O}_{4}$ yang selalu muncul dalam difraktogram XRD bahan $\mathrm{Fe}_{3} \mathrm{O}_{4}$. Ketika penambahan PEG kedalam sampel $\mathrm{Fe}_{3} \mathrm{O}_{4}$ terbentuk fasa $a-\mathrm{Fe}_{2} \mathrm{O}_{3}$ (hematit) dan fasa lain, yang muncul pada sudut $2 \theta=\sim 23,44^{\circ}$ yang ditunjukkan dengan (tanda $\mathrm{O}$ ) yang merupakan $a-\mathrm{FeO}(\mathrm{OH})$ dan pada sudut $2 \theta=\sim 26,95^{\circ}$ yang ditunjukkan dengan (tanda \#) merupakan $\gamma$ - $\mathrm{FeO}(\mathrm{OH})$.

Kemunculan fasa lain selain $\mathrm{Fe}_{3} \mathrm{O}_{4}$ pada puncak difraksi pada kisaran sudut $2 \theta=32^{\circ}$ yang ditunjuk dengan (tanda $*$ ) dalam sampel $\mathrm{Fe}_{3} \mathrm{O}_{4}$ menunjukkan kehadiran fasa $\alpha-\mathrm{Fe}_{2} \mathrm{O}_{3}$ (hematit) di dalam bahan $\mathrm{Fe}_{3} \mathrm{O}_{4} . \mathrm{Fe}_{2} \mathrm{O}_{3}$ merupakan material antiferromagnetik dengan struktur heksagonal dan terbentuk di dalam sampel yang diprediksi sebagai akibat proses oksidasi $\mathrm{Fe}_{3} \mathrm{O}_{4}$. Namun, secara kualitatif dapat diprediksi bahwa keberadaan fasa $a-\mathrm{Fe}_{2} \mathrm{O}_{3}$ didalam sampel $\mathrm{Fe}_{3} \mathrm{O}_{4}$ hanya dalam kadar yang cukup kecil. Hal ini dapat dikaji dari pola difraksi yang dihasilkan hanya dalam intensitas yang kecil. Selain itu, sampel yang diperoleh dari proses sintesis ini juga didominasi oleh warna hitam pekat yang menunjukkan ciri khas bahan $\mathrm{Fe}_{3} \mathrm{O}_{4}$, sedangkan $\alpha-\mathrm{Fe}_{2} \mathrm{O}_{3}$ memiliki penampilan fisis yang dicirikan dengan warna coklat [5].

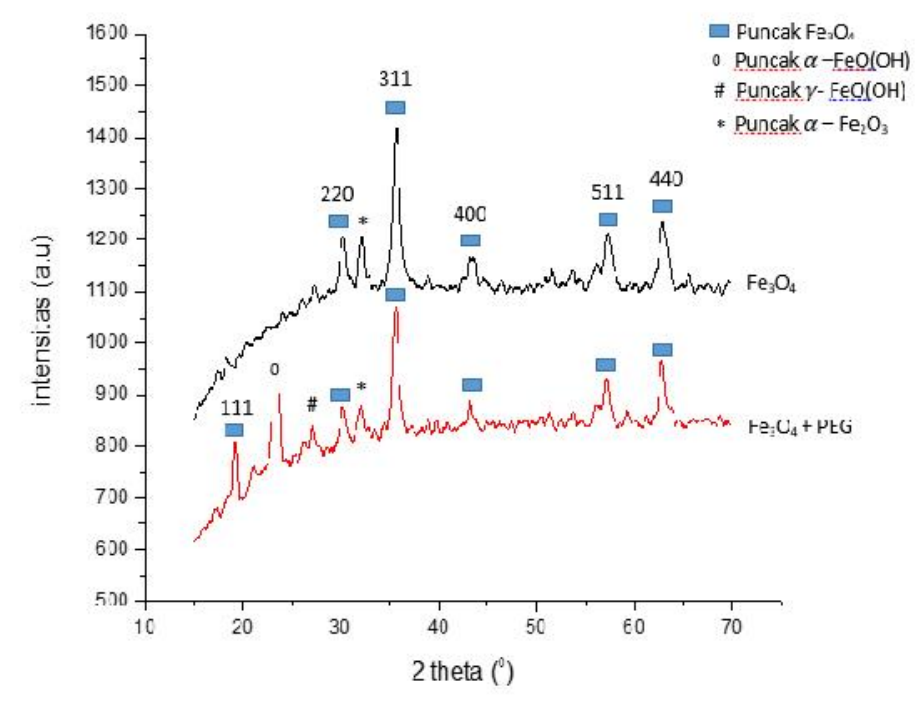

Gambar 1. (color online) Hasil XRD perbandingan $\mathrm{Fe}_{3} \mathrm{O}_{4}$ dengan $\mathrm{Fe}_{3} \mathrm{O}_{4}+\mathrm{PEG}$ (Polyethylene Glycol) [4] 
Hasil TEM pada Gambar 2 menunjukkan bahwa ukuran partikel tidak merata. Distribusi ukuran partikel paling banyak pada ukuran partikel $12 \mathrm{~nm}$. Pada gambar bagian kanan terlihat adanya bentuk cincin-cincin. Garis putus-putus pada pola cincin menunjukkan terjadinya difraksi, sehingga dapat diidentifikasikan indeks miller dari cincin paling dalam sampai terluar berturut-turut (220), (311), (400), (511) dan (440). Hasil TEM ini sama seperti yang diperoleh pada hasil XRD.

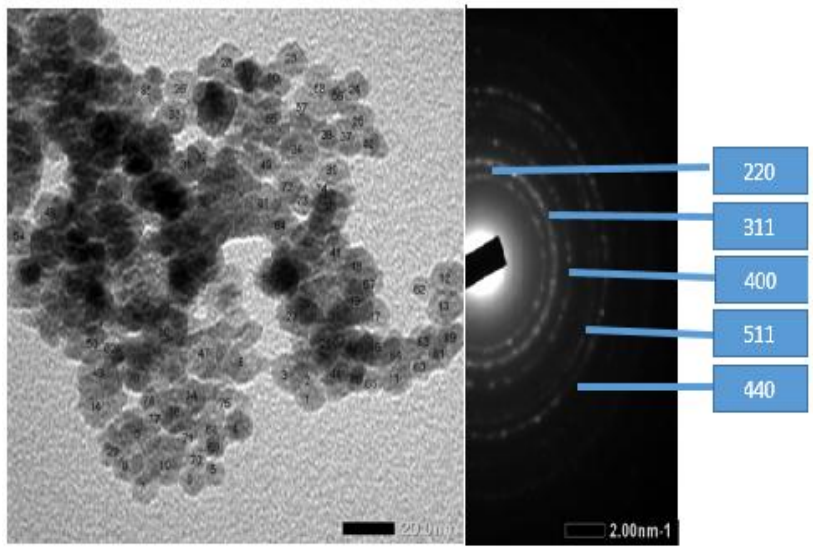

Gambar 2. (color online) Hasil TEM nanopartikel $\mathrm{Fe}_{3} \mathrm{O}_{4}[4]$

Berdasarkan hasil VSM diperoleh kurva loop histerisis untuk sampel $\mathrm{Fe}_{3} \mathrm{O}_{4}$ seperti pada Gambar 3. dengan nilai medan koersif 47,5 Oe. Pengukuran sifat kemagnetan yang disajikan dalam bentuk kurva loop histerisis memberikan informasi bahwa nanopartikel magnetit $\mathrm{Fe}_{3} \mathrm{O}_{4}$ yang disentesis ini memiliki sifat superparamagnetik, hal ini dapat dilihat dari bentuk kurva superparamagnetik. Sampel $\mathrm{Fe}_{3} \mathrm{O}_{4}$ ini memiliki magnetisasi remanen sebesar 7,846 emu/g dan magnetisasi saturasi $\left(\mathrm{M}_{\mathrm{s}}\right)$ sebesar 77,16 emu/g. Magnetisasi saturasi yang diperoleh ini jauh lebih kecil daripada material bulknya yang memiliki magnetisasi saturasi $\mathrm{M}_{\mathrm{s}} \sim 98 \mathrm{emu} / \mathrm{g}$.

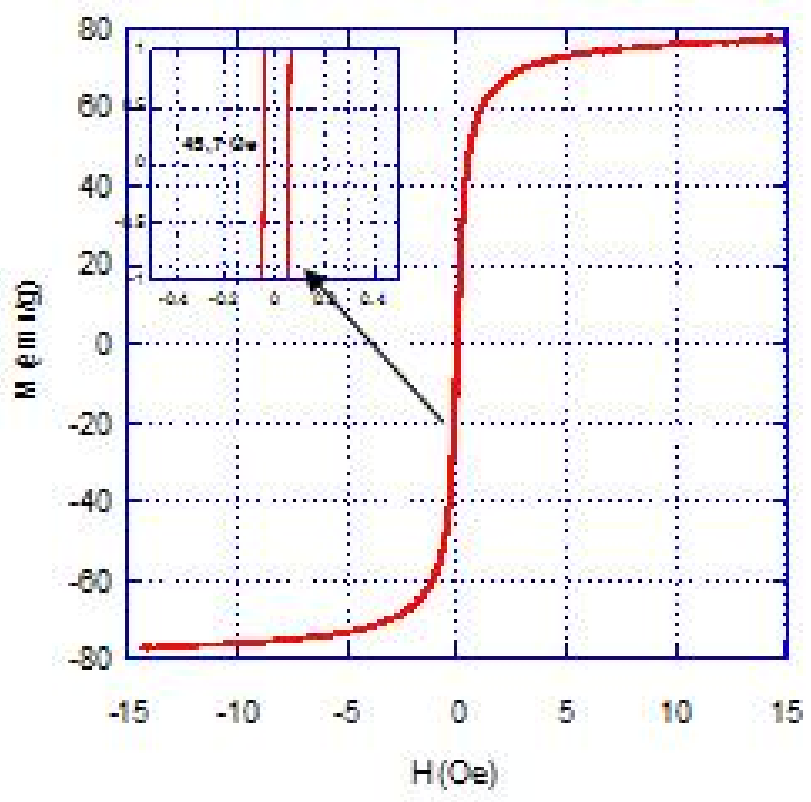

Gambar 3. (color online) Kurva hysteresis loop $\mathrm{Fe}_{3} \mathrm{O}_{4}[2]$ 
Sifat superparamagnetik dari nanopartikel $\mathrm{Fe}_{3} \mathrm{O}_{4}$ membuatnya sangat rentan terhadap medan magnet luar, dengan memberikan sedikit medan magnet nanopartikel dapat mengalami magnetisasi saturasi ${ }^{[6]}$. Dengan sifat yang mudah termagnetisasi maka nanopartikel $\mathrm{Fe}_{3} \mathrm{O}_{4}$ merupakan material soft magnetic ${ }^{[7]}$.

Sampel $\mathrm{Fe}_{3} \mathrm{O}_{4}$ dilapisi dengan PEG dan dikarakterisasi dengan TEM yang ditunjukkan pada Gambar 4. Hasilnya, ukuran partikel dari $\mathrm{Fe}_{3} \mathrm{O}_{4}+$ PEG lebih kecil dibandingkan dengan ukuran partikel $\mathrm{Fe}_{3} \mathrm{O}_{4}$ yaitu berukuran $11 \mathrm{~nm}$. Sampel PEG disini berfungsi sebagai template yang berperilaku sebagai surfaktan. Penambahan PEG ke dalam sampel membuat partikel $\mathrm{Fe}_{3} \mathrm{O}_{4}$ terjebak di dalam rantai PEG sehingga pertumbuhan kristalnya terhalangi. Pada gambar bagian kanan Gambar 4 juga terlihat adanya bentuk cincin-cincin. Garis putusputus pada pola cincin menunjukkan terjadinya difraksi, sehingga dapat diidentifikasikan indeks millernya. Hasilnya sama dengan yang diperoleh dari hasil XRD.

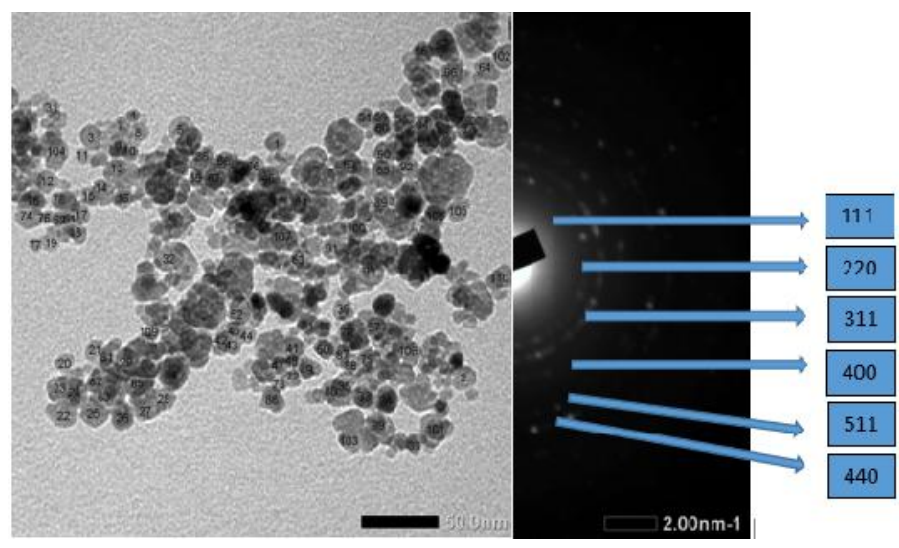

Gambar 4. (color online) $\mathrm{Hasil} \mathrm{TEM} \mathrm{Fe}_{3} \mathrm{O}_{4}+\mathrm{PEG}^{[4]}$

\section{1. Serapan Logam $\mathrm{Cu}, \mathrm{Mn}$ dan $\mathrm{Ni}$}

\section{Pengaruh pH}

Tabel 1. Menunjukkan pengaruh $\mathrm{pH}$ terhadap penurunan kadar logam yang diserap oleh nanopartikel $\mathrm{Fe}_{3} \mathrm{O}_{4}$. Dalam penelitian ini, $\mathrm{pH}$ artificial limbah dikondisikan mewakili $\mathrm{pH}$ asam dan basa. Prosentase penurunan kadar logam $\mathrm{Cu}^{+2}, \mathrm{Mn}^{+2}$ dan $\mathrm{Ni}^{+2}$ meningkat seiring dengan peningkatan $\mathrm{pH}$. Penurunan kadar logam maksimum terjadi pada $\mathrm{pH} 12$ (kondisi basa) masing-masing untuk $\mathrm{Cu} 99,79 \%$, $\mathrm{Ni} 69,83 \%$ dan $\mathrm{Mn} 44,53 \%$. Hal ini dapat terjadi karena adsorben $\mathrm{Fe}_{3} \mathrm{O}_{4}$ memiliki $\mathrm{pH}$ at the Point of Zero Charge (pHpzc). pHpzc adalah $\mathrm{pH}$ ketika permukaan adsorben bermuatan netral. Berdasarkan data yang diperoleh dari literatur, $\mathrm{Fe}_{3} \mathrm{O}_{4}$ memiliki pHpzc sebesar 6,3. Di bawah nilai tersebut, permukaan $\mathrm{Fe}_{3} \mathrm{O}_{4}$ bermuatan positif dan anion dari logam akan diadsorpsi secara elektrostatik oleh permukaan $\mathrm{Fe}_{3} \mathrm{O}_{4}$ sedangkan diatas nilai tersebut, permukaan $\mathrm{Fe}_{3} \mathrm{O}_{4}$ bermuatan negatif dan kation akan diadsorpsi oleh permukaan $\mathrm{Fe}_{3} \mathrm{O}_{4}{ }^{[8]}$. 


\begin{tabular}{|c|c|c|c|c|c|c|}
\hline \multirow[t]{2}{*}{ No } & \multirow[t]{2}{*}{ Parameter } & \multirow[t]{2}{*}{ Raw material (A) } & & \multicolumn{3}{|c|}{$\mathbf{p H}$} \\
\hline & & & & 5 & 9 & 12 \\
\hline \multirow[t]{2}{*}{1} & $\mathrm{Cu}$ & 396,929 & Rata - rata & 37,242 & 1,172 & 0,847 \\
\hline & & & Prosentase penurunan $(\%)$ & 90,62 & 99,70 & 99,79 \\
\hline \multirow[t]{2}{*}{2} & $\mathrm{Ni}$ & 240,132 & Rata - rata & 195,84 & 102,902 & 72,458 \\
\hline & & & Prosentase penurunan $(\%)$ & 18,44 & 57,15 & 69,83 \\
\hline \multirow[t]{2}{*}{3} & $\mathrm{Mn}$ & 443,952 & Rata - rata & 425,652 & 326,292 & 246,243 \\
\hline & & & Prosentase penurunan $(\%)$ & 4,12 & 26,50 & 44,53 \\
\hline
\end{tabular}

\section{Pengaruh Ukuran Partikel}

Tabel 2. Menunjukkan hasil pengujian pengaruh variasi ukuran partikel $\mathrm{Fe}_{3} \mathrm{O}_{4}$ terhadap penurunan kadar logam. Adsorben $\mathrm{Fe}_{3} \mathrm{O}_{4}$ dengan ukuran $12 \mathrm{~nm}$ mempunyai kemampuan menyerap logam $\mathrm{Cu}$, Mn dan $\mathrm{Ni}$ lebih banyak daripada $\mathrm{Fe}_{3} \mathrm{O}_{4}$ dengan ukuran $80 \mu \mathrm{m}$. Hal ini dikarenakan ukuran partikel yang kecil memiliki luas permukaan kontak yang lebih besar sehingga lebih banyak logam yang diadsorpsi oleh permukaan adsorben ${ }^{[8]}$.

Tabel 2. Pengaruh Ukuran Partikel

\begin{tabular}{|c|c|c|c|c|c|}
\hline \multirow[t]{2}{*}{ No } & \multirow[t]{2}{*}{ Parameter } & \multirow[t]{2}{*}{ Raw material (A) } & & \multicolumn{2}{|c|}{ Ukuran Partikel $\mathrm{Fe}_{3} \mathrm{O}_{4}$} \\
\hline & & & & $12 \mathrm{~nm}$ & $80 \mu \mathrm{m}$ \\
\hline \multirow[t]{2}{*}{1} & $\mathrm{Cu}$ & 396,929 & Rata - rata & 1,172 & 4,363 \\
\hline & & & Prosentase penurunan $(\%)$ & 99,70 & 98,90 \\
\hline \multirow[t]{2}{*}{2} & $\mathrm{Ni}$ & 240,132 & Rata - rata & 102,902 & 156,325 \\
\hline & & & Prosentase penurunan $(\%)$ & 57,15 & 34,90 \\
\hline \multirow[t]{2}{*}{3} & $\mathrm{Mn}$ & 443,952 & Rata - rata & 326,292 & 402,063 \\
\hline & & & Prosentase penurunan $(\%)$ & 26,50 & 9,44 \\
\hline
\end{tabular}

\section{Pengaruh Readsorpsi}

Readsorpsi merupakan proses adsorpsi berulang. Pada penelitian ini adsorpsi dilakukan sebanyak dua kali pada kondisi yang sama yaitu pH larutan 9 dan waktu pengadukan 3 jam.

Pada proses adsorpsi pertama, kadar awal logam $\mathrm{Cu}$, $\mathrm{Mn}$ dan $\mathrm{Ni}$ masing-masing sebesar 1,172 ppm, 326,292 ppm dan 102,902 ppm, berhasil diturunkan menjadi 0,014 ppm, 213,591 ppm dan 27,757 ppm pada proses adsorpsi kedua. Peningkatan penyerapan logam pada proses adsorpsi kedua mencapai $100 \%$. Hasil penelitian ini memberikan informasi bahwa semakin banyak proses pengulangan, penurunan kadar logam yang terlarut semakin besar. 
Tabel 3. Pengaruh Readsorpsi

\begin{tabular}{|c|c|c|c|c|c|}
\hline \multirow[t]{2}{*}{ No } & \multirow[t]{2}{*}{ Parameter } & \multirow[t]{2}{*}{ Raw material (A) } & & \multicolumn{2}{|c|}{ Adsorpsi } \\
\hline & & & & Pertama & Kedua \\
\hline \multirow[t]{2}{*}{1} & $\mathrm{Cu}$ & 390,929 & Rata - rata & 1,172 & 0,014 \\
\hline & & & Prosentase penurunan $(\%)$ & 99,70 & 99,99 \\
\hline \multirow[t]{2}{*}{2} & $\mathrm{Ni}$ & 240,132 & Rata - rata & 102,902 & 27,757 \\
\hline & & $140=0$ & Prosentase penurunan $(\%)$ & 57,15 & 88,44 \\
\hline \multirow[t]{2}{*}{3} & $\mathrm{Mn}$ & 445,952 & Rata - rata & 326,292 & 213,59 \\
\hline & & & Prosentase penurunan $(\%)$ & 26,50 & 51,89 \\
\hline
\end{tabular}

\section{Pengaruh Pelapisan Adsorben $\mathrm{Fe}_{3} \mathrm{O}_{4}$ dengan PEG}

PEG berfungsi sebagai template, yang membungkus partikel sehingga tidak terbentuk agregat lebih lanjut, dikarenakan PEG menempel pada permukaan partikel dan menutupi ion positif yang bersangkutan untuk bergantung dan membesar, sehingga pada akhirnya akan diperoleh partikel dengan bentuk bulatan yang seragam ${ }^{[9]}$. Oleh karena itu, $\mathrm{Fe}_{3} \mathrm{O}_{4}$ yang dilapisi dengan PEG mengadsorpsi ion logam lebih baik dibandingkan dengan $\mathrm{Fe}_{3} \mathrm{O}_{4}$ yang tidak dilapisi PEG. Peningkatan penyerapan ion logam yang baik tampak pada penyerapan ion logam Ni semula prosentase penurunannya sebesar $57,15 \%$ meningkat menjadi $88,54 \%$ dan $\mathrm{Mn}$ semula prosentase penurunannya 26,50 meningkat hingga dua kali lipatnya. Sedangkan pada ion logam $\mathrm{Cu}$, penggunaan $\mathrm{Fe}_{3} \mathrm{O}_{4}$ yang dilapisi dengan PEG tidak terlalu berpengaruh secara signifikan.

\section{KESIMPULAN}

Nanopartikel $\mathrm{Fe}_{3} \mathrm{O}_{4}$ (magnetit) secara efektif dapat digunakan sebagai adsorben untuk menurunkan kadar ion logam $\mathrm{Cu}, \mathrm{Mn}$ dan $\mathrm{Ni}$ dalam artificial limbah. Prosentase penurunan kadar ion logam sangat dipengaruhi oleh $\mathrm{pH}$. Penurunan kadar logam maksimum terjadi pada pH 12 (kondisi basa) masing-masing untuk $\mathrm{Cu}$ 99,79\%, Ni 69,83\% dan $\mathrm{Mn}$ 44,53\%. Selain itu, penggunaan adsorben $\mathrm{Fe}_{3} \mathrm{O}_{4}$ dengan ukuran $12 \mathrm{~nm}$ juga lebih efektif menyerap logam lebih banyak daripada $\mathrm{Fe}_{3} \mathrm{O}_{4}$ dengan ukuran $80 \mu \mathrm{m}$. Proses pengulangan (readsorpsi) dan pelapisan dengan PEG juga meningkatkan kemampuan nanopartikel $\mathrm{Fe}_{3} \mathrm{O}_{4}$ dalam mengadsorpsi ion logam sehingga persentase penurunan kadar logam juga mengalami peningkatan yang signifikan.

\section{DAFTAR PUSTAKA}

1 Wang X. S., Zhu L., Lu H. J., Surface properties and adsorption of $\mathrm{Cu}$ (II) on nanoscale magnetite in aqueous solutions, Journal of Desalination, vol. 276, 2011, pp. 154-160.

2 Riyanto A., Sintesis nanopartikel $\mathrm{Fe}_{3} \mathrm{O}_{4}$ (magnetit) dan potensinya sebagai bahan material aktif pada permukaan sensing biosensor berbasis surface Plasmon resonance (SPR), Thesis, Universitas Gadjah Mada, Yogyakarta,2012.

3 Gao M., Li W., Dong J., Zhang Z., Yang B., Synthesis and characterization of superparamegnetic $\mathrm{Fe}_{3} \mathrm{O}_{4} @ \mathrm{SiO}$ core-shell composite nanoparticles, World Journal of Condensed Matter Physic, vol. 1, 2011, pp. 49-54. 
4 Nuzully S., Karakteristik sifat kemagnetan pada Polyethene Glycol (PEG) - coated nanopartikel magnetit untuk pengikat DNA, Thesis, Universitas Gadjah Mada, Yogyakarta,2013.

5 Carlos L., Einschlag F.S.G., Gonzales M.C., Martire D.O., Applications of magnetite nanoparticles for heavy metal removal from wastewater: Article, Universidad Nacional de La Plata, Argentina, 2013.

6 Larraza I., Gonzales M.L., Corrales T., Marcelo G., Hybrid Materials: MagnetitePolyethylenimine-Montmorillonite, as magnetic adsorbents for $\mathrm{Cr}(\mathrm{VI})$ water treatment, Journal of Colloid and Interface Science, vol. 385, 2012, pp. 24-33.

7 Peterson M.L., White A.F., Brown G.E., Parks G.A., Surface passivation of magnetite by reaction with aqueous Cr (VI): XAFS and TEM results, Environ. Sci. Technnol, vol. 31, 1999, pp. 1573-1576.

$8 \mathrm{Lu}$ A.H., Salabas E.L., Schuth F., Magnetic nanoparticles: synthesis, protection, functionalization, and application: A review, Angew. Chem, vol. 46, 2007, pp. 1222-1244. A.Yan, X. Liu, G. Qiu, H. Wu, R. Yi, N. Zhang, J. Xu, Solvothermal synthesis and characterization of size- nanocomposite, J. Env. Sci. Technol, vol. 44, 2010, pp. 1927-1933.

$9 \mathrm{Lu}$ A.H., Salabas E.L., Schuth F., Magnetic nanoparticles: synthesis, protection, functionalization, and application: A review, Angew. Chem, vol. 46, 2007, pp. 1222-1244. 